\begin{tabular}{|c|l|}
\hline Title & A berrant Expression of HOX Genes in Oral Dysplasia and Squamous Cell Carcinoma Tissues \\
\hline Author(s) & $\begin{array}{l}\text { Hassan, Nur Mohammad Monsur; Hamada, Jun-ichi; Murai, Taichi; Seino, A kihusa; Takahashi, Y oko; T ada, } \\
\text { Mitsuhiro; Zhang, Xiuru; Kashiwazaki, Haruhiko; Yamazaki, Yutaka; Inoue, Nobuo; Moriuchi, Tetsuy a }\end{array}$ \\
\hline Citation & Oncology Research, 16(5), 217-224 \\
\hline Issue Date & 2006 \\
\hline Doc URL & http:/hdl.handle.net/2115/18638 \\
\hline Type & article (author version) \\
\hline File Information & CR16-5.pdf \\
\hline
\end{tabular}

Instructions for use 


\section{Aberrant Expression of HOX Genes in Oral Dysplasia and Squamous Cell}

\section{Carcinoma Tissues}

Nur Mohammad Monsur HASSAN ${ }^{1,2}$, Jun-ichi HAMADA ${ }^{1}$, Taichi MURAI ${ }^{1}$, Akihusa SEINO $^{1}$, Yoko TAKAHASHI ${ }^{1,4}$, Mitsuhiro TADA ${ }^{1}$, Xiuru ZHANG ${ }^{1}$, Haruhiko KASHIWAZAKI ${ }^{2}$, Yutaka YAMAZAKI ${ }^{3}$, Nobuo, INOUE ${ }^{2}$ and Tetsuya MORIUCHI $^{1}$

${ }^{1}$ Division of Cancer-Related Genes, Institute for Genetic Medicine, Hokkaido University, Sapporo, Japan

${ }^{2}$ Division of Geriatric Stomatology, Department of Oral Health Science, Graduate School of Dental Medicine, Hokkaido University, Sapporo, Japan

${ }^{3}$ Oral Diagnosis and Oral Medicine, Department of Oral Pathobiological Science, Graduate School of Dental Medicine, Hokkaido University, Sapporo, Japan ${ }^{4}$ Present address: Department of Neuro-Oncology, University of Texas M. D. Anderson Cancer Center, 1515 Holcombe Blvd., Houston, TX 77030, USA

Corresponding author: Jun-ichi Hamada, Ph.D., Division of Cancer-Related Genes, Institute for Genetic Medicine, Hokkaido University, Kita-15, Nishi-7, Kita-ku, Sapporo 060-0815, Japan. TEL: +81-11-706-6083; FAX: +81-11-706-7870; e-mail: jhamada@igm.hokudai.ac.jp

Running title: Aberrant expressions of HOX genes in oral cancer Key words: HOX, oral squamous carcinoma, dysplasia, oral mucosa, metastasis 


\begin{abstract}
Human HOX genes consist of 39 genes and encode transcription factors that function as master developmental regulators. We hypothesized that the misexpression of HOX genes was associated with carcinogenesis and malignant progression. The expression levels of 39 HOX genes in 31 human oral squamous cell carcinoma (SCC), 11 dysplasia and 10 normal mucosa tissues were quantified by the real-time RT-PCR method. The expression levels of 18 HOX genes in the SCC tissues were significantly higher than those in the normal mucosa tissues. The dysplasia tissues showed higher expression of HOXA2, A3, B3 and D10 than normal mucosa tissues whereas they showed lower expression of HOXA1, B7, B9 and C8 than SCC. The SCC with lymph node metastasis showed high expression of HOXC6 compared to the SCC without it. These results suggest that misexpressions of particular HOX genes are implicated in the development of oral dysplasia and SCC.
\end{abstract}




\section{Introduction}

Homeobox genes function as master regulators of morphogenesis and cell differentiation during embryogenesis of animals (1). The genes contain a common sequence element of $180 \mathrm{bp}$, the homeobox, which encodes a highly conserved 60 amino acid homeodomain (HD). HD proteins function as transcription factors through their homeodomain, which binds to DNA in sequence-specific manner (2). The HD motif is found in approximately 20 families of homeobox-containing genes, one of which in vertebrates is called Hox gene. The human genome contains 39 HOX genes which are clustered in a similar arrangement of 13 paralog groups in 4 different chromosomal regions, HOXA, B, C and D (3). During embryonic morphogenesis, the HOX genes determine positional identity along the body axis in animals. Within each cluster, HOX genes located at the 3' end are expressed earlier and more anteriorly in the embryo than those in more 5 ' positions, which is the property called colinearity rule (4). HOX gene products are transcription factors which regulate the transcription of target genes such as cell adhesion molecules, growth factors and transcription factors (5-9). HOX genes are also expressed in some normal adult organs in characteristic patterns, suggesting their possible role in the maintenance of tissuespecific architecture besides their roles in embryogenesis (10-12).

Recently accumulating evidence indicates that the expression patterns of $39 \mathrm{HOX}$ genes are different between cancer tissues and normal tissues in some kinds of human solid cancer including renal, prostate, bladder and so on (13-15). We also found that the expression levels of HOXA11, A13, B9, D12 and D13 in cutaneous melanoma were higher than those in nevus pigmentosus (16). These findings suggest that disturbance in the normal pattern of HOX gene expression links up with carcinogenesis in a variety of organs. Some studies show the relation between 
malignant phenotypes of tumor cells and the HOX gene expression. HOXA1 and HOXC8 may play a key role in the acquisition of invasive and metastatic phenotypes of breast and prostate cancer cells, respectively $(17,18)$. Our previous studies showed that human lung cancer A549 cells transfected with HOXD3 gene acquired more metastatic, invasive and motile phenotypes $(19,20)$. Taken together, inappropriate expression of a particular HOX gene(s) is likely involved in tumor development and malignant progression such as invasion and metastasis, and the HOX gene(s) responsible for oncogenesis and/or tumor progression differs according to the organs or tissues from which the tumor cells have derived.

Oral squamous cell carcinoma (SCC) is an important issue of oral health worldwide (21). The oral SCC is often preceded by premalignant lesions (dysplasias) which are clinically diagnosed as leukoplakia or erythroplakia. Long-term follow-up studies showed that $11-36 \%$ of oral epithelial dysplasias transformed into SCC (2225), and that severe dysplasias were generally associated with a higher risk for malignant transformation than mild and moderate ones (25). Thus, oral SCC, if not all, is likely to develop in normal-dysplasia-carcinoma sequence. One of the most important pathological changes in the normal-dysplasia-carcinoma sequence of oral mucosa is the advancement of disorder in the structural organization of stratified squamous epithelium. In this context, we think that deregulated expressions of HOX genes are associated with disturbance of structural organization. In this study, we analyzed the HOX gene expression patterns in normal mucosa, premalignancy (dysplasias) and malignancy (SCC) to better understand the roles of HOX genes in the development and subsequent progression of oral squamous cell carcinoma.

\section{Materials and methods}


Clinical Specimens. We used 31 oral SCC tissues, 11 dysplasia tissues (clinically diagnosed as leukoplakia) and 10 normal tissues from 46 patients who had undergone surgery at the Hokkaido University Hospital from January 2000 to September 2004. Three of 31 SCC tissues and 2 of 11 dysplasia tissues were originated from the same patient. Clinicopathologic data of each patient were shown in Table I. One to five bulk tissue samples of about $5 \mathrm{~mm}$-size were immediately cut from the oral tissues resected by a standard surgical procedure. The tissue samples were snap frozen in liquid nitrogen and stored at $-80^{\circ} \mathrm{C}$ until use. This study was approved by the Ethics Committee of Hokkaido University, and informed consent was obtained from all the patients.

RNA extraction and cDNA preparation. Total RNA was extracted from the clinical specimens by using Trizol (Invitrogen, Carlsbad, CA) according to the manufacturer's instruction. For real-time PCR, 1 microg of total RNA was subjected to cDNA synthesis in 100 microL of reaction mixture containing Taq Man RT buffer (Applied Biosystems, Foster City, CA), $5.5 \mathrm{mM} \mathrm{MgCl}_{2}, 500$ microM dNTP, 2.5 microM random hexamers, $0.4 \mathrm{U} /$ microL RNAase inhibitor, $1.25 \mathrm{U} /$ microL MultiScribe $^{\mathrm{TM}}$ reverse transcriptase. The reverse transcription reaction was performed sequentially for $10 \mathrm{~min}$ at $25^{\circ} \mathrm{C}$, for $30 \mathrm{~min}$ at $48^{\circ} \mathrm{C}$ and for $5 \mathrm{~min}$ at $95^{\circ} \mathrm{C}$.

Quantitative real-time RT-PCR. Quantitative RT-PCR assays were carried out by using ABI PRISM 7900HT (Applied Biosystems) with SYBR-green fluorescence. Real-time PCR amplification was performed in 20 microL of reaction mixture containing 2 microL of cDNA sample, 10 microL of QuantiTect ${ }^{\mathrm{TM}}$ SYBR Green PCR Master Mix (Qiagen, Valencia, CA) and with specific primer sets which had been described in our previous report (11). PCR was carried out by starting with a 15-min hot start at $95^{\circ} \mathrm{C}$, followed by a denaturation step at $94^{\circ} \mathrm{C}$ for $15 \mathrm{sec}$, an annealing step 
at $60^{\circ} \mathrm{C}$ for $30 \mathrm{sec}$ and an extension step at $72^{\circ} \mathrm{C}$ for $1 \mathrm{~min}$ for 40 cycles. Dissociation curve analysis $\left(95^{\circ} \mathrm{C}\right.$ for $15 \mathrm{sec}, 60^{\circ} \mathrm{C}$ for $15 \mathrm{sec}$, and $95^{\circ} \mathrm{C}$ for $15 \mathrm{sec}$ ) was performed at the end of 40 cycles to verify the identity of the PCR product. Data were analyzed by using Sequence Detector Systems version 2.0 software (Applied Biosystems). Quantification was done by using the standard curve method as described in our previous report (11). Finally we represented relative gene expression levels as the ratio of the target HOX gene to the internal reference gene (beta-actin) expression based on the initial copy number calibrated along the standard curve.

Statistical analysis and cluster analysis. The relationship between each HOX gene expression and each clinicopathological parameter was determined by the MannWhitney U test or the Kruskal-Wallis rank test. The statistical software package applied was Statview 5.0 for Macintosh (SAS Institute, Cary, NC). A p value less than 0.01 was considered statistically significant.

\section{Results}

Expression of HOX genes in normal oral mucosa tissues. Expression levels of 39 HOX genes in 10 normal mucosa tissues are shown in Figure 1. Relative expression ratios of each HOX gene belonging to cluster A, B and C (HOXA, HOXB and HOXC) against beta-actin gene were less than 0.002 in all the specimens. Of these HOX genes, HOXA2 and B2 showed relatively high expression compared to the others. HOXD3, D4, D8 and D9 which belong to cluster D showed the highest expression levels among 39 HOX genes.

\section{Differences in HOX gene expression between normal mucosa, dysplasia and} squamous cell carcinoma. We compared the expression levels of each HOX genes among normal mucosa (10 specimens), dysplasia (11 specimens) and squamous cell 
carcinoma (SCC) (31 specimens) to examine whether the HOX gene expression changed with the advance of disease or not. In 18 genes (HOXA1, A2, A3, A5, A9, B3, B6, B7, B9, C4, C6, C8, C9, C11, C13, D9, D10 and D11) of 39 HOX genes, their expression levels were significantly different among normal, dysplasia and cancerous mucosa ( $\mathrm{p}<0.01$, Kruskal-Wallis rank test, Figure 2). The expression levels of all the 18 HOX genes in SCC were high compared to those in normal mucosa ( $\mathrm{p}<0.01$, Mann-Whitney U test). The expression levels of HOXA2, A3, B3 and D10 were significantly high in the dysplasia tissues compared to normal mucosa tissues ( $\mathrm{p}<0.01$, Mann-Whitney U test) whereas there was no difference in their expression levels between dysplasia and SCC tissues. The dysplasia tissues showed significantly low expressions of HOXA1, B7, B9 and C8 compared to SCC ( $<<0.01$, Mann-Whitney U test).

\section{Differences in HOX gene expression between SCC with lymph node}

metastasis and SCC without it. To find the particular HOX genes involved in progressive phenotypes, we compared the expression levels of each HOX gene between SCC with lymph node metastasis and SCC without it. The SCC with lymph node metastasis tended to show high expressions of HOXC5, C6 and C8 which were adjacent genes on the cluster C compared to the SCC without it; especially the expression level of HOXC6 was significantly higher in the metastatic SCC than the non-metastatic ones ( $\mathrm{p}<0.01$, Mann-Whitney U test) (Figure 3).

\section{Discussion}

This is the first report describing the systemic analysis of 39 HOX gene expressions in oral normal mucosa, dysplasia and squamous cell carcinoma tissues. All normal mucosa tissues examined here showed relatively high expression levels of 
the HOX genes located at 3'-side of each cluster, except HOXC cluster. Yahagi et al analysed the expression patterns of $39 \mathrm{HOX}$ genes in gastrointestinal tract tissues including esophagus, stomach, duodenum, jejunum, ielum, ileocecum, cecum, ascending colon, transverse colon, descending colon and rectum but not oral cavity (12). They found the expression level of HOX paralogs apparently reflected the paralog number and relative position along the anteroposterior axis; for example, the first three paralogs in each group were highly expressed in the organs derived from foregut such as esophagus and stomach. In this context, it is reasonable that normal mucosa of oral cavity which is at more anterior position than esophagus or stomach showed high expression of 3'-side of HOX genes. It was also characteristic that the expression levels of HOXD8 and D9 were highest in all of the HOX genes examined. This is consistent with our previous observation that HOXD8 and D9 were highly expressed in salivary gland, thyroid, trachea, lung, thymus which were at relatively anterior position along the body axis (11).

Comparison of the expression levels in normal mucosa, dysplasia and SCC tissues found different expressions of 18 HOX genes among them. Expression levels of all the 18 HOX genes were high in SCC compared to those in normal mucosa. Of the 18 HOX genes, 4 HOX genes (HOXA1, B7, B9 and C8) showed higher expression in SCC than in dysplasia, and 4 other HOX genes (HOXA2, A3, B3 and D10) showed higher expression in dysplasia than in normal mucosa. In the remainder $10 \mathrm{HOX}$ genes, there was no significant difference in the expression levels between dysplasia and normal mucosa or SCC. This evidence suggests that the expression of HOX genes sequentially alters from normal mucosa, dysplasia and SCC. Of the $18 \mathrm{HOX}$ genes, 11 genes were the adjacent genes on the same cluster (A1/A2/A3, B6/B7, C6/C8/C9, and D9/D10/D11). This observation suggests the possibility that these 
adjacent HOX genes are cis-activated and controlled by common upstream regulatory components.

It is also interesting that almost half of the $18 \mathrm{HOX}$ genes are known to be affected by fibroblast growth factors (FGF). Studies on Hox gene expression in chick embryos show that FGF modified the expressions of Hoxa2, b6-9, c6-9 and d9 (2629). The expression levels of FGF-1 nad FGF-2 are higher in SCC than in normal oral mucosa (30), and high affinity receptors for FGFs, FGFR2 and FGFR3, are highly expressed in dysplasia and SCC compared to those in normal mucosa (31). Therefore, FGFs may contribute to malignancy of oral cavity through alteration of HOX gene expression since FGFs influence growth of a variety of tissues including solid tumor tissues (32, 33).

We showed here that the expression levels of HOXC6 were significantly higher in SCCs with lymph node (LN) metastasis than those without LN metastasis. There was a tendency to increase expressions of HOXC5 and C8 which were neighboring on HOXC6 in SCCs with LN metastasis compared to those without LN metastasis. A gene expression analysis of microdissected human prostate tissues demonstrates that HOXC6 is significantly overexpressed in the epithelium of prostate cancer (34). Loss of HOXC6 expression by siRNA targetting HOXC6 induces apoptosis in human prostate cancer cell lines (35). Moreover, human prostate cancer cell lines established from LN metastases showed high expression of HOXC4, C5 and C6, especially C6, compared to cell lines derived from primary site or metastases from other sites (18). O'Donnell et al reported that the expression of HOXC8 was upregulated in primary oral cavity squamous cell carcinomas with LN metastasis (36). Thus, the incresed expression of HOXC4-8 may be associated with malignacy including LN metastasis in not only prostate but also oral SCC. 
Our results strongly support our hypothesis that aberrant expression of HOX genes is associated with the development of oral dysplasia and SCC. However, before we can reveal the roles of HOX genes in the oral malignancy, we need further studies to uncover which type of cells in tumor (or dysplasia) tissues misexpress the HOX genes and the target genes whose transcriptions are regulated by theHOX genes.

\section{Acknowledgment}

The authors wish to thank Ms. Masako Yanome for her help in preparing the manuscript. This work was supported in part by Grant-in-Aid for Scientific Research (B) (J.H.) and Grant-in-Aid for Scientific Research (C) (H.K.) from the Ministry of Education, Culture, Sports, Science and Technology of Japan.

\section{References}

1. Gehring, W.J.; Hiromi, Y. Homeotic genes and the homeobox. Annu. Rev. Genet. 20: 147-173; 1986.

2. Levine, M.; Hoey, T. Homeobox proteins as sequence-specific transcription factors. Cell 55: 537-540; 1988.

3. Ruddle, F.H.; Bartels, J.L.; Bentley, K.L.; Kappen, C.; Murtha, M.T.; Pendleton, J.W. Evolution of Hox genes. Annu. Rev. Genet. 28: 423-442; 1994.

4. Krumlauf, R. Hox genes in vertebrate development. Cell 78: 191-201; 1994.

5. Boudreau, N.J.; Varner, J.A. The homeobox transcription factor Hox D3 promotes integrin alpha5beta1 expression and function during angiogenesis. J. Biol. Chem. 279: 4862-4868; 2004.

6. Jones, F.S.; Prediger, E.A.; Bittner, D.A.; De Robertis, E.M.; Edelman, G.M. Cell adhesion molecules as targets for Hox genes: neural cell adhesion molecule promoter activity is modulated by cotransfection with Hox-2.5 and -2.4. Proc. Natl. Acad. Sci. U S A. 89: 2086-2090; 1992. 
7. Care, A.; Silvani, A.; Meccia, E.; Mattia, G.; Stoppacciaro, A.; Parmiani, G.; Peschle, C.; Colombo, M.P. HOXB7 constitutively activates basic fibroblast growth factor in melanomas. Mol. Cell. Biol. 16: 4842-4851; 1996.

8. Raman, V.; Martensen, S.A.; Reisman, D.; Evron, E.; Odenwald, W.F.; Jaffee, E.; Marks, J.; Sukumar, S. Compromised HOXA5 function can limit p53 expression in human breast tumours. Nature 405: 974-978; 2000.

9. Guazzi, S.; Lonigro, R.; Pintonello, L.; Boncinelli, E.; Di Lauro, R.; Mavilio, F. The thyroid transcription factor-1 gene is a candidate target for regulation by Hox proteins. EMBO J. 13: 3339-3347; 1994.

10. van Oostveen, J.; Bijl, J.; Raaphorst, F.; Walboomers, J.; Meijer, C. The role of homeobox genes in normal hematopoiesis and hematological malignancies. Leukemia 13: 1675-1690, 1999.

11. Takahashi, Y.; Hamada, J.; Murakawa, K.; Takada, M.; Tada, M.; Nogami, I.; Hayashi, N.; Nakamori, S.; Monden, M.; Miyamoto, M.; Katoh, H.; Moriuchi, T. Expression profiles of 39 HOX genes in normal human adult organs and anaplastic thyroid cancer cell lines by quantitative real-time RT-PCR system. Exp. Cell Res. 293: 144-153; 2004.

12. Yahagi, N.; Kosaki, R.; Ito, T.; Mitsuhashi, T.; Shimada, H.; Tomita, M.; Takahashi, T.; Kosaki, K. Position-specific expression of Hox genes along the gastrointestinal tract. Congenit. Anom. 44: 18-26; 2004.

13. Cillo, C.; Cantile, M.; Mortarini, R.; Barba, P.; Parmiani, G.; Anichini, A. Differential patterns of HOX gene expression are associated with specific integrin and ICAM profiles in clonal populations isolated from a single human melanoma metastasis. Int. J. Cancer 66: 692-697; 1996.

14. Waltregny, D.; Alami, Y.; Clausse, N.; de Leval, J.; Castronovo, V. Overexpression of the homeobox gene HOXC8 in human prostate cancer correlates with loss of tumor differentiation. Prostate 50: 162-169; 2002. 
15. Cantile, M.; Cindolo, L.; Napodano, G.; Altieri, V.; Cillo C. Hyperexpression of locus $\mathrm{C}$ genes in the HOX network is strongly associated in vivo with human bladder transitional cell carcinomas. Oncogene 22: 6462-6468; 2003.

16. Maeda, K.; Hamada, J.; Takahashi, Y.; Tada, M.; Yamamoto, Y.; Sugihara, T.; Moriuchi, T. Altered expressions of HOX genes in human cutaneous malignant melanoma. Int. J. Cancer 114: 436-441; 2005.

17. Zhang, X.; Zhu, T.; Chen, Y.; Mertani, H.C.; Lee, K.O.; Lobie, P.E. Human growth hormone-regulated HOXA1 is a human mammary epithelial oncogene. J. Biol. Chem. 278: 7580-7590; 2003.

18. Miller, G.J.; Miller, H.L.; van Bokhoven, A.; Lambert, J.R.; Werahera, P.N.; Schirripa, O.; Lucia, M.S.; Nordeen, S.K. Aberrant HOXC expression accompanies the malignant phenotype in human prostate. Cancer Res. 63: 5879-5888; 2003.

19. Hamada, J.; Omatsu, T.; Okada, F.; Furuuchi, K.; Okubo, Y.; Takahashi, Y.; Tada, M.; Miyazaki, Y.J.; Taniguchi,Y.; Shirato, H.; Miyasaka, K.; Moriuchi, T. Overexpression of homeobox gene HOXD3 induces coordinate expression of metastasis-related genes in human lung cancer cells. Int. J. Cancer 93: 516-525; 2001.

20. Okubo, Y.; Hamada, J.; Takahashi, Y.; Tada, M.; Tsutsumida, A.; Furuuchi, K.; Aoyama, T.; Sugihara, T.; Moriuchi, T. Transduction of HOXD3-antisense into human melanoma cells results in decreased invasive and motile activities. Clin. Exp. Metastasis 19: 503-511; 2002.

21. Sciubba, J.J. Oral cancer. The importance of early diagnosis and treatment. Am. J. Clin. Dermatol. 2: 239-251; 2001.

22. Lumerman, H.; Freedman, P.; Kerpel, S. Oral epithelial dysplasia and the development of invasive squamous cell carcinoma. Oral. Surg. Oral. Med. Oral. Pathol. 79: 321-329; 1995. 
23. Sudbo, J.; Kildal, W.; Risberg, B.; Koppang, H.S.; Danielsen, H.E.; Reith, A. DNA content as a prognostic marker in patients with oral leukoplakia. N. Engl. J. Med. 344: 1270-1278; 2001.

24. Silverman, S.J.; Gorsky, M.; Lozada, F. Oral leukoplakia and malignant transformation. A follow-up study of 257 patients. Cancer 53: 563-568; 1984.

25. Banoczy, J.; Csiba, A. Occurrence of epithelial dysplasia in oral leukoplakia: Analysis and follow-up study of 12 cases. Oral Surg. 42: 766-774; 1976.

26. Bel-Vialar, S.; Itasaki, N.; Krumlauf, R. Initiating Hox gene expression: in the early chick neural tube differential sensitivity to FGF and RA signaling subdivides the HoxB genes in two distinct groups. Development 129: 5103-5115; 2002.

27. Cohn, M.J.; Patel, K.; Krumlauf, R.; Wilkinson, D.G.; Clarke, J.D.; Tickle, C. Hox9 genes and vertebrate limb specification. Nature 387: 97-101; 1997.

28. Trainor, P.A.; Ariza-McNaughton, L.; Krumlauf, R. Role of the isthmus and FGFs in resolving the paradox of neural crest plasticity and prepatterning. Science 295: 1288-1291; 2002.

29. Liu, J.P.; Laufer, E.; Jessell, T.M. Assigning the positional identity of spinal motor neurons: rostrocaudal patterning of Hox-c expression by FGFs, Gdf11, and retinoids. Neuron 32: 997-1012; 2001.

30. Myoken, Y.; Myoken, Y.; Okamoto, T.; Sato, J.D.; Takada, K.(1994). Immunocytochemical localization of fibroblast growth factor-1 (FGF-1) and FGF-2 in oral squamous cell carcinoma (SCC). J. Oral Pathol. Med. 23: 451-456; 1994.

31. Wakulich, C.; Jackson-Boeters, L.; Daley, T.D.; Wysocki, G.P. Immunohistochemical localization of growth factors fibroblast growth factor- 1 and fibroblast growth factor- 2 and receptors fibroblast growth factor receptor-2 and fibroblast growth factor receptor-3 in normal oral epithelium, epithelial dysplasias, 
and squamous cell carcinoma. Oral Surg. Oral Med. Oral Pathol. Oral Radiol. Endod. 93: 573-579; 2002.

32. Basilico, C.; Moscatelli, D. The FGF family of growth factors and oncogenes. Adv. Cancer Res. 59: 115-165; 1992.

33. Bikfalvi, A.; Klein, S.; Pintucci, G.; Rifkin, D.B. Biological roles of fibroblast growth factor-2. Endocr. Rev. 18: 26-45; 1997.

34. Ernst, T.; Hergenhahn, M.; Kenzelmann, M.; Cohen, C.D.; Bonrouhi, M.; Weninger, A.; Klaren, R.; Grone, E.F.; Wiesel, M.; Gudemann, C.; Kuster, J.; Schott, W.; Staehler, G.; Kretzler, M.; Hollstein, M.; Grone, H.J. Decrease and gain of gene expression are equally discriminatory markers for prostate carcinoma: a gene expression analysis on total and microdissected prostate tissue. Am. J. Pathol. 160: 2169-2180; 2002.

35. Ramachandran, S.; Liu, P.; Young, A.N.; Yin-Goen, Q.; Lim, S.D.; Laycock, N.; Amin, M.B.; Carney, J.K.; Marshall, F.F.; Petros, J.A.; Moreno, C.S. Loss of HOXC6 expression induces apoptosis in prostate cancer cells. Oncogene 24: 188-198, 2005.

36. O'Donnell, R.K.; Kupferman, M.; Wei, S.J.; Singhal, S.; Weber, R.; O'Malley, B.; Cheng, Y.; Putt, M.; Feldman, M.; Ziober, B.; Muschel, R.J. Gene expression signature predicts lymphatic metastasis in squamous cell carcinoma of the oral cavity. Oncogene 24: 1244-1251; 2005. 


\section{Figure legends}

Figure 1

Expression profiling of 39 HOX genes in oral normal mucosa tissues. The relative levels of HOX mRNA determined by quantitative RT-PCR (described in the Materials and Methods) in 10 normal mucosa tissues. The graphs of HOX cluster A, $\mathrm{B}, \mathrm{C}$ and $\mathrm{D}$ are lined from top to bottom. HOX gene paralogs from 1 to 13 are lined from left to right of the abscissa axis in each graph. The distribution of the relative expression ratio (HOX/beta-actin) is summarized by using boxplots. The central box in each plot shows the interquartile (25th to 75th percentile) range. The line in the box shows the median. The whiskers (vertical bars) were drawn to the 90th and 10th percentiles. Extreme values higher than the 90th percentile or lower than the 10th percentile were marked with circles individually.

\section{Figure 2}

Different expression levels of HOX genes among normal mucosa, dysplasia and squamous cell carcinoma tissues. The distribution of the relative expression ratio (HOX/beta-actin) was summarized by using boxplots in the same manner as in Figure 1. C: Squamous cell carcinoma; D: dysplasia; N: Normal mucosa tissues. P values were calculated by the Man-Whitney U-test following the Kruskal-Wallis rank test.

\section{Figure 3}

Different expression levels of HOX genes between squamous cell carcinoma (SCC) with lymph node metastasis and SCC without it. The distribution of the relative expression ratio (HOX/beta-actin) was summarized by using boxplots in the same manner as in Figure 1. HOXC5, C6 and C8 were overexpressed in SCC with lymph 
node metastasis compared to SCC without metastasis $(\mathrm{p}=0.0352,0.0034$ and 0.0390, respectively, by Mann-Whitney U-test). 

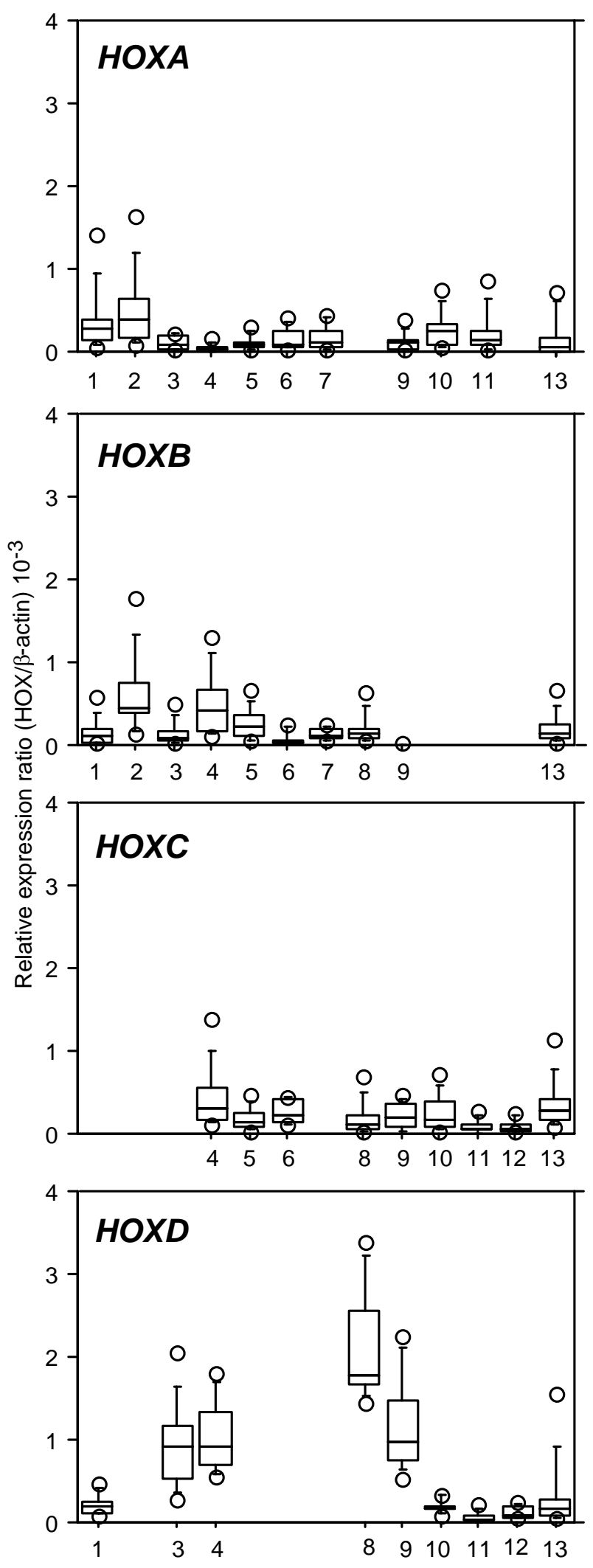

Figure 1 


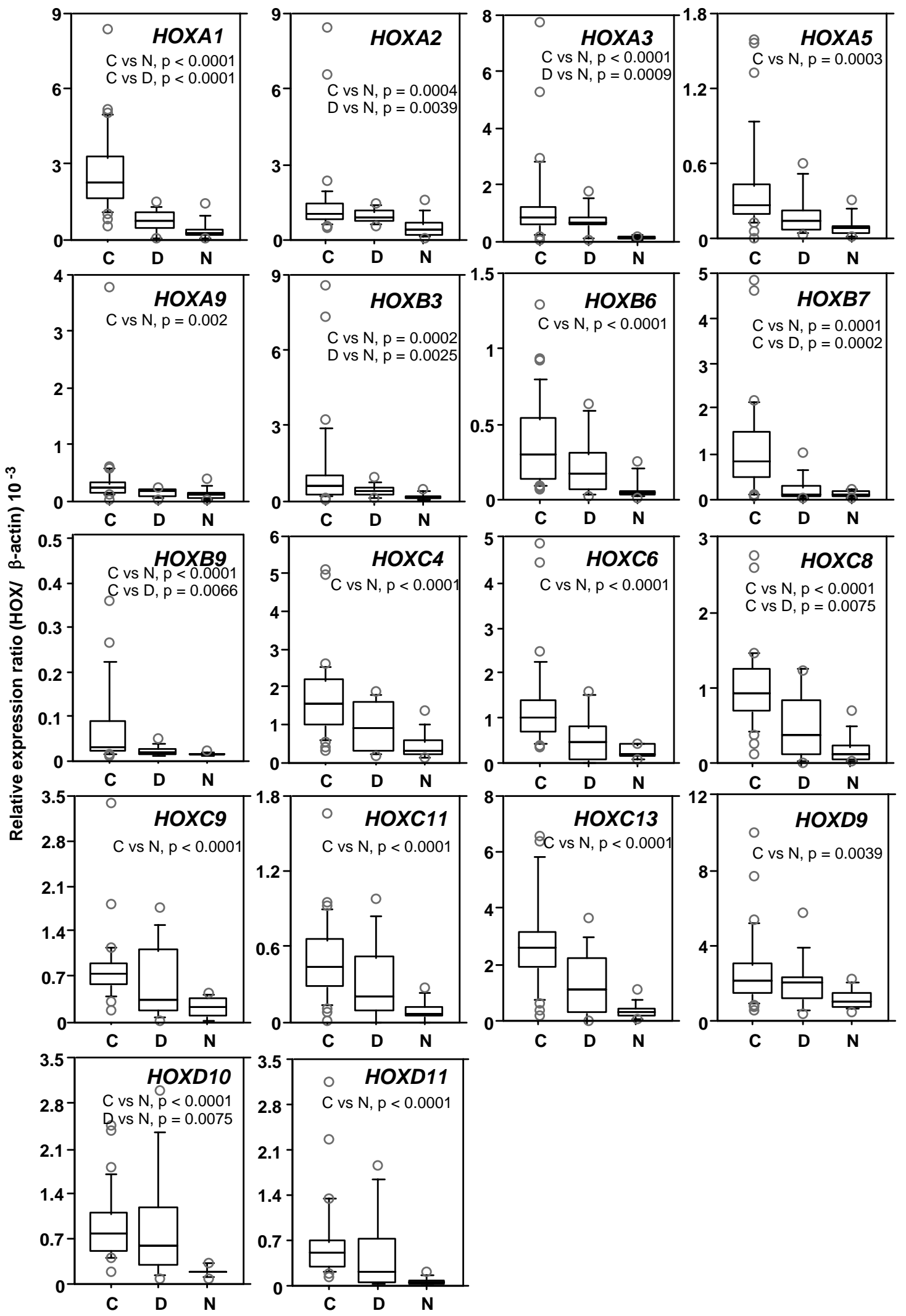

Figure 2 


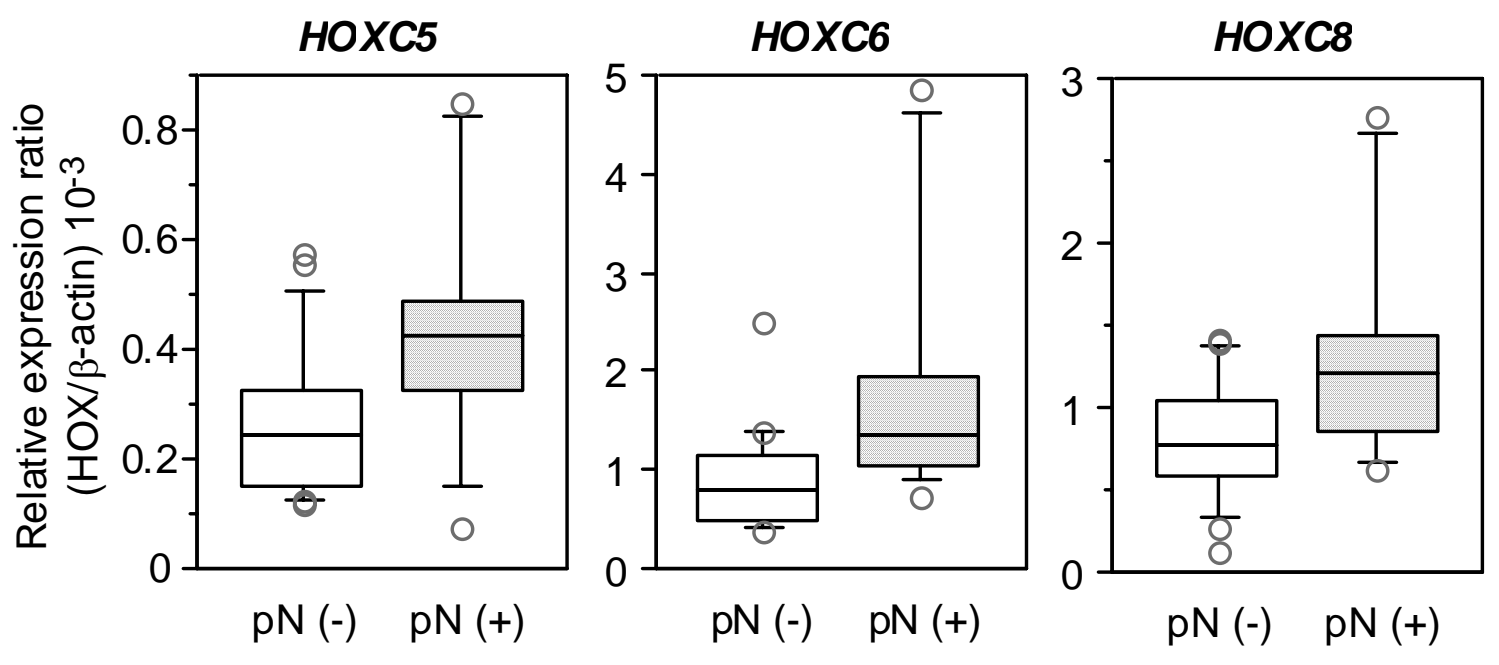

Figure 3 
Table I Clinicopathologic data of all patients and samples examined

\begin{tabular}{|c|c|c|c|c|c|}
\hline Patient code & Sample code & Histology & $\mathrm{T}^{\mathrm{a}}$ & $\mathrm{pN}^{\mathrm{a}}$ & Location \\
\hline \#11 & C11 & SCC & 1 & 0 & Tongue \\
\hline \#14 & C14 & SCC & 1 & 0 & Tongue \\
\hline \#20 & $\mathrm{C} 20$ & SCC & 1 & 0 & Tongue \\
\hline \#25 & C25 & SCC & 1 & 0 & Tongue \\
\hline \#1 & $\mathrm{C} 1$ & SCC & 2 & 0 & Tongue \\
\hline \#3 & C3 & SCC & 2 & 0 & Tongue \\
\hline \#5 & C5 & SCC & 2 & 0 & Tongue \\
\hline \#10 & C10 & SCC & 2 & 0 & Tongue \\
\hline \#22 & C22 & SCC & 2 & 0 & Tongue \\
\hline \#28 & $\mathrm{C} 28$ & SCC & 2 & 0 & Tongue \\
\hline \#4 & $\mathrm{C} 4$ & SCC & 2 & 1 & Cheek \\
\hline \#7 & C7 & SCC & 2 & 1 & Cheek \\
\hline \#26 & C26 & SCC & 2 & 0 & Cheek \\
\hline \#13 & C13 & SCC & 2 & 0 & Floor \\
\hline \#19 & C19 & SCC & 2 & 0 & Floor \\
\hline$\# 12$ & C12 & SCC & 2 & 0 & Gingiva (maxilla) \\
\hline \#15 & C15 & SCC & 2 & 0 & Gingiva (mandible) \\
\hline$\# 17$ & C17 & SCC & 2 & 1 & Gingiva (mandible) \\
\hline \#16 & C16 & SCC & 3 & $2 b$ & Tongue \\
\hline$\# 18$ & C18 & SCC & 3 & 1 & Tongue \\
\hline \#23 & C23 & SCC & 3 & 0 & Tongue \\
\hline \#21 & $\mathrm{C} 21$ & SCC & 3 & 0 & Gingiva (mandible) \\
\hline$\# 27$ & $\mathrm{C} 27$ & SCC & 3 & 1 & Gingiva (mandible) \\
\hline \#8 & C8 & SCC & 4 & 2c & Tongue \\
\hline \#30 & C32 & SCC & 4 & 2c & Tongue (L) \\
\hline \#2 & $\mathrm{C} 2$ & SCC & 4 & 1 & Cheek \\
\hline \#6 & C6 & SCC & 4 & 0 & Cheek \\
\hline$\# 9$ & C9 & SCC & 4 & 0 & Gingiva (maxilla) \\
\hline$\# 24$ & $\mathrm{C} 24$ & SCC & 4 & 0 & Gingiva (maxilla) \\
\hline \#30 & C30 & SCC & 4 & 2c & Gingiva (mandible)(L) \\
\hline \#30 & C31 & SCC & 4 & $2 c$ & Gingiva (mandible)(R) \\
\hline \#31 & $\mathrm{D} 1$ & Dysplasia (mild) & & & Tongue \\
\hline \#32 & D2 & Dysplasia (mild) & & & Tongue \\
\hline \#33 & D3 & Dysplasia (mild) & & & Tongue \\
\hline \#35 & D5 & Dysplasia (mild) & & & Tongue \\
\hline \#36 & D6 & Dysplasia (mild) & & & Tongue \\
\hline$\# 40$ & D11 & Dysplasia (mild) & & & Tongue \\
\hline \#37 & D7 & Dysplasia (moderate) & & & Tongue \\
\hline \#38 & D9 & Dysplasia (moderate) & & & Tongue \\
\hline \#30 & D21 & Dysplasia (moderate) & & & Gingiva (maxilla) \\
\hline \#34 & D4 & Dysplasia (severe) & & & Tongue \\
\hline \#30 & D22 & Dysplasia (severe) & & & Gingiva (maxilla) \\
\hline \#41 & $\mathrm{N} 1$ & Normal & & & Gingiva (mandible) \\
\hline \#42 & N2 & Normal & & & Gingiva (mandible) \\
\hline \#43 & N3 & Normal & & & Gingiva (mandible) \\
\hline \#44 & N4 & Normal & & & Gingiva (mandible) \\
\hline \#45 & N5 & Normal & & & Gingiva (mandible) \\
\hline \#46 & N6 & Normal & & & Gingiva (mandible) \\
\hline \#47 & N7 & Normal & & & Gingiva (mandible) \\
\hline \#48 & N8 & Normal & & & Gingiva (mandible) \\
\hline \#49 & N9 & Normal & & & Gingiva (mandible) \\
\hline \#50 & N10 & Normal & & & Gingiva (mandible) \\
\hline
\end{tabular}

${ }^{\mathrm{a}} \mathrm{T}$ and $\mathrm{pN}$ of each samples were categorized according to the UICC TNM classification. 